Ousar crer, ousar criar:

Cristianismo e literatura

brasileira contemporânea

Dare to believe, dare to create:

Christianity and contemporary

Brazilian literature

\section{Luciano Santos}

Ao mano e compadre Paulo César.

"Cristo é a juventude do mundo."

Hélio Pellegrino

\section{Resumo:}

Tendo como fio condutor a exposição re-

*Doutor em Filosofia pela Pontifícia Universidade Católica do Rio Grande do Sul, com estágio doutoral no Institut Catholique de Paris-Université de Poitiers. Atualmente é professor adjunto da Universidade do Estado da Bahia, credenciado no Programa de Pós-Graduação em Educação e Contemporaneidade; e professor visitante na

Pós-Graduação em Filosofia Contemporânea da Faculdade São Bento da Bahia. Integra o

Grupo de Pesquisa Filosofia

Moderna e Contemporânea

da UFBA. É membro do Centro

Brasileiro de Estudos sobre

o Pensamento de Emmanuel Levinas (CEBEL); sócio-fundador da Associação Sul-Americana de Filosofia e Teologia Interculturais

(ASAFTI); e membro da Associação Latino Americana de Literatura e Teologia (ALALITE). sumida e concatenada de alguns dos mais significativos escritores brasileiros contemporâneos de inspiração cristã católica em seus respectivos contextos históricos, o presente artigo tem como foco principal discutir a relação do campo cristão com a assim chamada cultura moderna no Brasil, ao longo do século passado, descrevendo-se o processo que vai de um cristianismo aqui denominado "de reação" a um cristianismo "de transformação". Dentre outros aspectos envolvidos na relação entre cristianismo e modernidade, discute-se em especial a possibilidade e legitimidade de articular a perene novidade da revelação cristã com uma concepção estética libertária, conciliando a ousadia de crer e a ousadia de criar.

Palavras-chave: cristianismo; modernidade; reação; criação. 


\section{Abstract}

This paper focuses primarily discuss the relationship of the Christian camp with the so called modern culture in Brazil over the past century, describing the process that goes here called Christianity "reaction" to a Christianity "transformation " since some of the most significant writers of contemporary Brazilian Catholic Christian inspiration in their respective historical contexts. Among other aspects involved in the relationship between Christianity and modernity, especially discusses the possibility and legitimacy of articulating the perennial newness of Christian revelation with a libertarian aesthetic design, combining boldness and daring to believe created.

Keywords: Christianity; modernity; reaction; creation.

\section{Introdução}

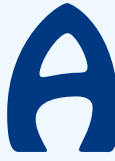

presentamos a seguir um breve panorama da literatura brasileira contemporânea de inspiração cristã, tendo como fio condutor a exposição resumida e concatenada de alguns de seus mais significativos nomes, nos respectivos contextos históricos. Embora seja dada prioridade à literatura de ficção (poesia e romance), nem por isso descartaremos a literatura de ideias. A fim de que os escritores ganhem voz, o escorço biográfico e contextual será complementado com a citação de um ou outro trecho significativo de suas obras. A restrição do foco de exposição sobre a literatura brasileira contemporânea permitirá uma discussão mais abrangente sobre a relação do campo cristão católico com a cultura brasileira contemporânea, da qual a assim chamada modernidade, com os sucessivos movimentos de liberação e emancipação que a caracterizam, constitui, por assim dizer, a espinha dorsal.

\section{Mário de Andrade: uma oração "futurista?"}

A questão de fundo que aqui se tem em vista é a seguinte: qual a posição do cristianismo ante as transformações literárias e culturais no Brasil contemporâneo? Em especial: como o cristianismo dialoga com a cultura moderna? E, por extensão: como se constituiu entre nós uma cul- 
tura cristã católica em franco confronto com os movimentos de liberação (estética, social, política) da modernidade, de modo que o mero qualificativo de "católico" passou a soar praticamente como sinônimo de "reacionário" e "anti-moderno"? Por outro lado, dentre os escritores referidos nesse panorama, acaso há quem tenha alcançado fecunda conciliação entre cristianismo e modernidade, tradição espiritual e emancipação estética? Quer-nos parecer que a atenta consideração dessas questões abrirá importante perspectiva para o exame do futuro das relações entre cristianismo e cultura no Brasil.

A deixa para a abordagem dessas questões surgiu ao nos depararmos com o sugestivo trecho de uma carta de Mário de Andrade a Manuel Bandeira, datada de 14 de Janeiro de 1925, em que o autor de "Paulicéia Desvairada", e grande mentor do movimento modernista brasileiro, confessa ao amigo sua apreensão teológica em torno do poemaprece "Reza de fim de ano", escrito um ano antes:

Aí vai este poema escrito faz um ano. (...) meu irmão acha que não está ortodoxo - por causa daquela história de oferecer pra Deus o meu pecado. Isso me entristece porque eu queria bem ortodoxa esta reza. Sei que isso não é questão que interesse o pensamento de você. Mas me interessa. Ando discutindo dentro de mim. Mas tenho vergonha também de perguntar pra um padre. Eles andam tão afastados de futurismo. Acredito mesmo que pensam que fazer uma oração futurista já é pecado... coitados! ${ }^{1}$

Concebida no réveillon de 1923, na referida "Reza" o poeta derramase a Deus com intimidades de salmista, partilhando as alegrias e dores de sua vida em plena efervescência modernista:

Senhor, é 31.../ Deixei a noite lá./ Paulicéia alegre, farrista,/ Sacudida em fordes, dodges.../ (...)/ Senhor, é 31.../ Eu te agradeço este ano que me deste./ Que o novo seja igual ao que passou!/ Alegrias bombásti-

1. Moraes, Marco Antônio de (Org.). Correspondência - Mário de Andrade \& Manuel Bandeira. São Paulo: EDUSP/IEB, 2000, p. 178. Grifo nosso. 
cas/ Sofrimentos redundantes/ Retumbantes/ Samba/ Villa Lobos/ Os meus amigos de Paris/ Águas-fortes de Seewald/ Águas-fortes de Chagall/ Sangue/ Pranto e riso/ Quanta coisa! Quanta coisa!...2

A questão, portanto, é: quem são esses "padres", esta cultura eclesiástica, essa Igreja, enfim, da época de Mário de Andrade, que andavam tão "afastados de futurismo", e para os quais seria virtual "pecado" fazer um poema-prece "futurista"? O que haveria de teologicamente sacrílego ou, ao menos, de heterodoxo no gesto "futurista" do escritor, e no futurismo como tal? A fim de abordar essa questão, convém considerar previamente o que significa, afinal, futurismo.

Em sentido estrito, "futurismo" refere-se à escola literária fundada pelo poeta italiano Fillippo Tommaso Marinetti (1876-1944), que propõe uma arte livre, capaz de expressar a energia e dinamismo da moderna sociedade industrial. Por extensão, o termo passou a designar "literatura moderna" e, mais amplamente, "arte moderna" ou, ainda, "arte de vanguarda".

Nesse sentido ampliado, as principais correntes estéticas "futuristas" ou modernas, de fins do século XIX e início do século $X X$, além do próprio futurismo de Marinetti, foram, simplificadamente: 1) Impressionismo: de maior incidência nas artes plásticas, concebe a arte não como cópia da "realidade", mas invenção autônoma, ou obra em si mesma; visa captar o real no instante em que ele se manifesta, e traduzi-lo com os elementos de cada linguagem artística; 2) Expressionismo: a arte é livre expressão dos fluxos subjetivos do artista; 3) Cubismo: representa as formas da natureza em sua esquematização geométrica, como construções do olhar do artista; 4) Surrealismo: a arte é livre expressão das imagens do inconsciente - ou "meta-racional"; 5) Dadaísmo: destitui o artista como sujeito da criação artística, submetendo-a ao puro acaso; o non-sense é a atmosfera da arte, que é, pois, francamente "irracional".

2. Andrade, Mário de. Cartas a Anita Malfatti. Rio de Janeiro: Forense Universitária, 1989 , p. 68. 
Cotejando as correntes de vanguarda acima mencionadas, ressaltam os seguintes elementos-chave da arte moderna: arte como pura criação; experimentação formal permanente, cuja principal manifestação, em campo literário, é o "verso livre"; intensificação do estilo autoral, singular, do artista; autonomia da obra de arte face à realidade aparente; busca das fontes pré-"civilizadas", "bárbaras", de inspiração (arte "popular", "primitiva", "naïfe"). Em suma, na arte moderna trata-se de assumir a pulsão criadora como principal moto gerador da arte; esta é tanto mais autêntica quanto mais deixa acontecer o livre encontro do artista com a obra, sem sujeição prévia a qualquer ordem - metafísica, moral ou lingüística - externa.

Como dissemos, Mário de Andrade foi um dos maiores expoentes da arte moderna no Brasil, seja como mentor, seja como criador. Ao mesmo tempo, era de formação católica, tendo sido congregado mariano e irmão vicentino até a idade adulta; e católico permaneceu, por íntima convicção, até o fim da vida, como amiúde o atesta sua vasta epistolografia. ${ }^{3}$ Essa improvável configuração identitária do escritor constituiu a fonte de uma tensão insolúvel: como conciliar a profissão estética modernista e o estilo de vida moderno com a sua profissão de fé católica, numa sociedade em que o catolicismo representava a ordem estabelecida, avessa às transformações históricas e culturais? Como ser, portanto, "modernista" e católico? Em carta a Alceu Amoroso Lima, de 6 de Outubro de 1931, Mário assim resume o seu impasse:

É horrível talvez, mas eu estou nisso. Ateu? Anticatólico? Nunquíssimo. Católico? Isso agora já não sei mais; não por mim, que todas as minhas fibras me afirmam que sou católico, mas por esse lado das leis sociais da catolicidade, que como toda religião o Catolicismo foi obrigado a se dar, e a que eu desrespeito. Desrespeito não porque lhes falte ao respeito, mas porque não estou

3. Cf. Santos, Luciano Costa. "Elegia de Jacó, o homem". In: O Passeio da Coruja. Rio de Janeiro: Ed. Leviatã, 1994, pp. 61 e ss. 
dentro delas. ${ }^{4}$

Noutra passagem de sua correspondência com Alceu, Mário chega a designar como "paracatolicismo" a sua singular profissão de fé católica "modernista" à margem da sociedade vigente. O termo é revelador, pois reafirma a permanência do escritor no elemento da fé católica, ao tempo em que o situa fora ("para") do espaço ordinário da religião institucional. Ora, a poesia foi justamente um dos expedientes extra-ordinários de que se serviu Mário para dar vazão à sua viva, embora contida, fé "paracatólica", como se vê nos versos efusivos de "Carnaval carioca":

Meu Deus.../ Onde que jazem tuas atrações?/ Pra que lado de fora da Terra/ Fugiu a paz das naves religiosas/ E a calma boa de rezar ao pé da cruz?/ (...)/ Quedê teus padres?/ Quedê teus arcebispos purpurinos?/ Quedele o tempo em que Felipe Neri/ (...) / Agarrava a contar as parábolas lindas/ De que os padres não se lembram mais?/ Por onde pregam os Sumés de meu Senhor?/ Aqueles a quem deixaste a tua Escola/ Fingem ignorar que gostamos de parábolas lindas,/ $E$ todos nos pusemos sapateando histórias de pecado/ Porque não tinha mais histórias pra escutar.../ Senhor! Deus bom, Deus grande sobre a terra e sobre/ o mar./ Grande sobre a alegria e o esquecimento humano,/ Vem de novo em nosso rancho, Senhor! $!^{5}$

Em versos de exílio espiritual, Mário canta saudades do tempo em que o Deus "bom", "grande sobre a alegria", era proclamado em "parábolas lindas" pelos seus missionários. Um Deus-esteta, afeito aos símbolos e às narrativas. Alguns versos adiante do mesmo "Carnaval carioca", o poeta - que em "Paulicéia Desvairada" já se auto-definira como "um tupi tangendo um alaúde"6 - salmodia a plena voz em seu inspirado estro mestiço, cristão-tropical:

4. In: Fernandes, Lygia (Org.) 71 Cartas de Mário de Andrade. Rio de Janeiro: Livraria São José, s/d, p. 47.

5. Andrade, Mário de. "Carnaval carioca". In: Poesias Completas. São Paulo/Belo Horizonte: EDUSP/Editora Itatiaia, 1987, pp. 168-169.

6. Idem, ibidem, p. 83. 


\begin{abstract}
Aleluia!/ Louvemos o Criador com os sons dos saxofones arrastados,/ Louvemo-lo com os salpicos dos xilofones nítidos!/ Louvemos o Senhor com os riscos dos recorrecos e os/ [estouros do tantã,/ Louvemo-lo com a instrumentada crespa do jazz-band!/ Louvemo-lo com os violões de cordas de tripa e as cor-/ deonas migrantes,/ Louvemo-Lo com as flautas dos choros mulatos e os cava-/ quinhos de serestas ambulantes!/ Louvemos O que permanece através das festanças virtuo-/ sas e dos gozos ilegítimos!/ Louvemo-Lo sempre e sobre tudo!/ Louvemo-Lo com todos/ os instrumentos e todos os ritmos!... ${ }^{7}$
\end{abstract}

Ousando uma ligeira caracterização, diríamos que Mário de Andrade foi um "paracatólico" moderno: ciosamente ortodoxo - católico tout court - em questões de fé, chegando a declarar-se "papista!"8 a amigos escritores anti-clericais; libertário do ponto de vista estético; e revolucionário nos planos social e político, tendo demonstrado gradual e acentuada tendência socialista e apoiado a rebelião anti-oligárquica de 1924 e a Revolução de 1930, que funda as bases do moderno Estado brasileiro. Assim, e como foi dito, a "paracatolicidade" do poeta modernista não se refere propriamente a qualquer hesitação quanto a princípios de fé, mas à sua impossibilidade de aderir à cultura católica - ordeira e acomodatícia - hegemônica na sociedade de seu tempo.

\title{
2. O modernismo brasileiro
}

Para entender melhor a relação de catolicismo e literatura (ou cultura) moderna, convém nos demorarmos um pouco mais nesse momento de fundação da arte moderna no Brasil e considerar as principais linhas do movimento modernista que se seguiu à Semana de Arte Moderna de 1922. De modo geral, não se registram significativas dissonâncias do nosso modernismo em relação às matrizes estéticas européias que the serviram de inspiração. Grosso modo, o que se viu, lá como aqui, foram

7. Idem, ibidem, p. 169.

8. Cf. Andrade, Mário de. Cartas de Mário de Andrade a Murilo Miranda. Rio de Janeiro:

Ed. Nova Fronteira, 1981, p. 115. 
sucessivos movimentos de irrupção ou liberação: da sensibilidade urbano-industrial: "Queremos luz, ar, ventiladores, aeroplanos, reivindicações obreiras, idealismos, motores, chaminé de fábricas, sangue, velocidade, sonho, na nossa Arte!" (Menotti Del Picchia, "Arte moderna”, 1922)ㅎ da jovialidade e da irreverência: "KLAXON cogita principalmente de arte. Mas quer representar a época de 1920 em diante. Por isso é polimorfo, onipresente, inquieto, cômico, irritante, contraditório, invejado, insultado, feliz." (KLAXON, 1922) ${ }^{10}$; da invenção artística: "Liberdade e Alegria. Guerra aos códigos literários, às fórmulas pré-estabelecidas. Guerra ao parnasianismo, ao gagaísmo, ao academismo, ao naturalismo da prosa, ao virtuosismo, ao conformismo, ao copismo, ao dicionarismo." "Joaquim Inojosa, "A arte moderna", 1924); da pulsão lírica: "A impulsão lírica é livre, independe de nós, independe de nossa inteligência. Pode nascer de uma réstia de cebolas como de um amor perdido (...) Todos os assuntos são vitais. Não há temas poéticos. Não há épocas poéticas."12 (Mário de Andrade, "A Escrava que não é Isaura", 1924); da cultura autóctone: "A poesia existe nos fatos. Os casebres de açafrão e de ocre nos verdes da Favela, sob o azul cabralino, são fatos estéticos. O Carnaval no Rio é o acontecimento religioso da raça." ${ }^{13}$ (Oswald de Andrade, "Manifesto Pau-Brasil", 1924); da sensibilidade nativa: "Tupy or not tupy, that is the question". ${ }^{14}$ (Oswald de Andrade, "Manifesto Antropófago", 1928).

Uma nota bastante característica do modernismo brasileiro, como se entrevê nas citações acima, é a articulação dos movimentos de liberação estética e emancipação nacional. Tratando-se de uma nação jovem e colonizada como a brasileira, a irrupção dos estratos mais profundos da sensibilidade não poderia senão incitar a conquista do direito a assumir

9. In: Teles, Gilberto Mendonça. Vanguarda Européia e Modernismo Brasileiro. Rio de Janeiro: Ed. Record, 1987, 10ª ed., p. 289.

10. Idem, ibidem, p. 295.

11. Idem, ibidem, p. 334.

12. Idem, ibidem, p. 304.

13. Idem, ibidem, p. 326.

14. Idem, ibidem, p. 353. "Tupi ou não tupi, eis a questão." 
o próprio jeito de ser e expressar-se e, pois, de pertencer a um lugar, povo e história irredutíveis a quaisquer outros. Ao despojar-se da crosta de formalismo e beletrismo que sufocava nossa expressão lírica, o modernismo também ousava remover o verniz de "civilização" estrangeira que nos impedia de viver nosso jeito único de ser. Assim, além de esteticamente inventivo, o modernismo brasileiro foi, também, culturalmente telúrico, nacionalizante e, mais adiante, popular - ou popularesco.

No entanto, de contrabando com toda essa liberação interior e expressiva, vieram os excessos estéticos e lingüísticos, como espontaneísmo, desleixo formal, irreverência gratuita e abuso do pitoresco e "folclórico", previsíveis e praticamente inevitáveis numa explosão cultural que foi, também e em larga medida, uma explosão juvenil.

\section{Tasso da Silveira: uma Festa modesta}

Ora, é precisamente nesse ponto que se situa o singular papel jogado pelo grupo de escritores da Revista Festa (1927), corrente modernista de inspiração católica articulada em tono da liderança sóbria e conscienciosa do poeta e ensaísta paranaense Tasso da Silveira (18951968), da qual também participaram Andrade Murici (1895-1984), Murilo Araujo (1894-1980), Adelino Magalhães (1887-1969) e - mais espiritualista que propriamente "católica" - a poeta Cecília Meireles (1901-1964), cujo talento maior apenas ensaiava os primeiros passos. O grupo de Festa adere convicto às principais contribuições estéticas do modernismo, como liberdade de criação, invenção formal/verso livre e sensibilidade brasileira; mas reage com veemência aos excessos acima mencionados, reivindicando mais exigência espiritual, equilíbrio humano, comedimento moral e pesquisa estética:

O grave perigo é que, pelo número, eles [os vulgarizadores do modernismo] acabaram fazendo ambiente. Ambiente de arte, de pensamento, de espiritualidade? Não. Ambiente de burrice, de "escárnio estéril", de licencioso deboche, de despreocupação das altas e puras meditações, de desprezo pelo trabalho da inteligência, 
de influxos deletérios sobre nossa formação mental, de íntima desvalorização de nossa alma de povo, de desprestígio de nossa língua saborosa, de bolchevicação geral. ${ }^{15}$

O emprego pejorativo do termo "bolchevicação" no sentido de vulgarização é sintomático da tendência anti-revolucionária e anti-comunista do grupo Festa, cujos integrantes, se não chegaram a aderir formalmente ao integralismo - versão brasileira do fascismo -, ao menos simpatizavam com ele.

Em longa e compreensiva análise do grupo, o crítico Tristão de Ataíde (Alceu Amoroso Lima) - cuja conversão à fé católica estava, então, em pleno curso - faz restrição ao termo "festa", por considerá-lo mais afim ao "modernismo dionisíaco, fácil, liberto", dos enfants terribles de São Paulo, do que ao "sentimento profundo de preocupação pela sorte do homem", próprio ao grupo católico. ${ }^{16}$ Articulando os pólos religioso/ tradicional e estético/moderno do grupo Festa, Tristão o qualifica de "tradicionismo dinâmico", expressão assim endossada por Tasso da Silveira: "Dinâmicos, por ansiedade criadora, pelo desejo invencível de construir o que por nossas mãos deve ser construído, por anelo da Realidade mais alta de que em nós mesmos temos a promessa, por sede e fome de plenitude." 17

Já o ensaísta Nestor Victor prefere caracterizar o grupo como "totalismo criador", justamente por essa "fome de plenitude" que o impele à integração das mais contrastantes dimensões da vida em busca da "Realidade mais alta", conforme se vê no poema-editorial de 1927, de autoria de Tasso da Silveira, considerado o manifesto de Festa:

O artista canta agora a realidade total:/ a do corpo e a do espírito,/ a da natureza e a do sonho,/ a do homem e a de Deus,/ canta-a, porém, porque a percebe

15. Silveira, Tasso da. Definição do Modernismo Brasileiro. Rio de Janeiro: Edições Forja, 1932, p. 53.

16. Apud idem, ibidem, p. 86.

17. Idem, ibidem, p. 85. 
e compreende/ em toda a sua múltipla beleza,/ em toda a sua profundidade e infinitude./ $\mathrm{E}$ por isto o seu canto/ é feito de inteligência e instinto/ (porque também deve ser total)/ e é feito de ritmos livres/ elásticos e ágeis como músculos de atletas/ velozes e altos como sutilíssimos pensamentos/ e sobretudo palpitantes/ do triunfo interior/ que nasce das adivinhações maravilhosas.../ O artista voltou a ter os olhos adolescentes/ e encantou-se novamente com a Vida:/ todos os homens o acompanharão! ${ }^{18}$

A respeito dessa "Vida" maiúscula que encanta Festa, e que the cabe cantar, em tão claro contraste com a feérica e efêmera euforia do frisson modernista, cuja fugidia pletora o poeta paracatólico Mário de Andrade oferecia compungido a Deus em sua "Prece de fim de ano", Tasso ressalta:

Vida com $\mathrm{V}$ grande. A vida com o seu esplendor de beleza e com o seu esplendor de sofrimento, que afirma o espírito. E nesta visão da Vida é que está a grande e pura alegria. A alegria, por exemplo, de um São Francisco de Assis. O mais é vacuidade e ceticismo. Fuga covarde. Lassidão. Festa - celebração, exaltação. Comunhão íntima do espírito com o sentido de eternidade da hora que passa. ${ }^{19}$

A Revista Festa constitui não uma reação doutrinária, mas uma resposta estética ao modernismo brasileiro da primeira hora; configura menos um outro ideário organizado do que outra sensibilidade. É menos milícia militante do que comunidade poético-contemplativa, posta no seu canto à margem da algazarra geral, trazendo um ritmo sóbrio, grave, meditativo, à "festa-farra" modernista. Tasso da Silveira anseia enraizar a libertação estética na tradição cristã, conciliando a experimentação estética com a mais exigente e angustiada aspiração espiritual. Tasso é, assim, um católico modernizante: nem tão ousado para ser estritamente moderno, nem tão reativo para ser anti-moderno. Certamente, não consideraria "pecado" uma "oração futurista"; em contrapartida, insta o

18. In Silveira, Tasso da, op. cit., p. 15.

19. Idem, ibidem, p. 87. 
"futurismo" a modular o seu tom e ritmo ao espírito da própria oração. Eis a tarefa de Festa: encontrar a expressão estética da espiritualidade cristã. Para tanto, não Ihe valeriam os versos saltitantes do modernismo de trincheira. Para a Liberdade da Fé, uma outra liberdade estética; para a Alegria da Fé, uma outra alegria vital. A propósito, Oswald de Andrade, o maior cultor do poema-piada, acusa o circunspecto grupo de Festa de promover uma "festa triste". Tasso responde-lhe sem sair do tom: "Oswald: eu escrevo as minhas páginas mais graves em alegria. Porque a alegria é grave." ${ }^{20}$

Embora situado no posto mais avançado do fragor modernista, Mário de Andrade, espírito enraizado na fé católica e de larga visão, logo simpatiza com as linhas gerais de Festa e, bem mais tarde, em artigo sobre Tasso da Silveira, de 1939, reconhece o alto valor intelectual e humano do mestre paranaense, rendendo tributo ao seu apostolado cultural: "Este artista apresenta a imagem quase brutal, em nosso meio, da coerência, da probidade silenciosa, do respeito pra com os seus próprios ideais." ${ }^{21}$ No entanto, mesmo sublinhando o valor literário da poesia de Tasso da Silveira, Mário cobra-Ihe mais força de criação e liberdade artística, arrefecidas sob o peso de tanto equilíbrio intelectual e correção moral:

Como poeta ele está longe do medíocre e por muitas partes é admirável, mas coibiu suas liberdades, evitou abismos, destruiu entusiasmos e forças, com o seu intransigente intelectualismo e a ambição quieta de criar dentro do certo e do já provado. A sua poesia traz frequentemente aquela monotonia das coisas cuidadosas; e, bem comportada como é, não foge muitas vezes àquela espécie de vulgaridade morna da virtude. ${ }^{22}$

Restaria, portanto, indagar - e a questão fica aqui em aberto - se e em que medida o grave contraponto aos arroubos juvenis do modernis-

20. Idem, ibidem, p. 78.

21. Andrade, Mário de. O Empalhador de Passarinho. São Paulo: Livraria Martins Editora, 1972, p. 93.

22. Idem, ibidem, p. 85. 
mo não terminou por desvigorar a própria jovialidade - jovialidade, nota bene, e não mera e pueril juvenilidade - da Festa de Tasso da Silveira.

\section{Jackson de Figueiredo: Reação Católica}

Retomando o fio de nossa meada, em que contexto cultural e eclesiástico a "oração futurista" veio a tornar-se, afinal, um virtual "pecado"? Qual a justificativa para a restrição teológica à estética modernista? Como se estabeleceu a incompatibilidade entre arte moderna e tradição religiosa, liberdade estética e fé?

Para abordar essas questões, cabe previamente repassar em sequência alguns fatos básicos. Não temos como nos achegar ao centro de nossa questão sem pisar com cuidado no chão da história.

Em meados da década de 1910, quando as sementes do modernismo estético apenas começavam a germinar, a Igreja no Brasil já se ressentia de importante refluxo histórico e esboça uma ampla reação para não perder sua hegemonia institucional na sociedade brasileira.

Desde as primeiras décadas do século XIX, cresce no Brasil imperial o prestígio da Maçonaria e o culto dos valores laicos, a reboque de um amplo processo de secularização que avança sobre todo o orbe ocidental. O direito, conferido ao Estado brasileiro pela Constituição de 1824, de nomear os sacerdotes ao preço de assumir suas despesas, gera uma disputa intestina de poder entre o Império e a Igreja, que estoura na "Questão religiosa" de 1872, cujo estopim foi a iniciativa tomada pelo bispo D. Vital, à revelia do Estado, de afastar de sua diocese sacerdotes envolvidos com a Maçonaria. Com a proclamação da República e a promulgação da Constituição de 1891, de inspiração positivista, ocorre a separação entre Igreja e Estado, com decisivas conseqüências para a vida social, a exemplo da supressão do ensino religioso nas escolas públicas e da obrigatoriedade do casamento civil, levando a uma gradativa 
redução da influência da Igreja na sociedade..$^{23}$

Esse recuo histórico da Igreja só fez acentuar-se com as intensas e sucessivas transformações em curso entre fins do século XIX e início do século $\mathrm{XX}$, originando uma nova e complexa ordem civilizatória que começava a enterrar os derradeiros resquícios da Cristandade medieval: transformações econômicas - industrialização, expansão da lavoura cafeeira e implementação do mercado interno; sociais - urbanização, imigração européia, crescimento das camadas médias e emergência do proletariado; políticas - organização política das camadas médias, greves proletárias, surgimento do comunismo, mobilização das Forças Armadas (que estoura na rebelião tenentista de 1922); e ideológicas expansão do positivismo, evolucionismo, liberalismo e comunismo, com a mentalidade racionalista, secularista, materialista e agnóstica que Ihes corresponde.

Marco da Reação Católica foi a publicação, em 1916, da Carta Pastoral de D. Sebastião Leme, arcebispo de Olinda e Recife, que conclama a grande maioria católica do país, "inoperante e asfixiada", a retomar com vigor o comando das ações sociais em meio às complexas transformações em curso. D. Leme parte do pressuposto de que o catolicismo constitui um dos fundamentos de nossa identidade nacional; sustenta que a secularização moderna, pondo em risco a hegemonia católica, abala as bases morais da própria ordem social; e defende a recristianização - ou re-catolicização - da sociedade como solução para a crise civilizatória que começava a instalar-se.

Em 1921, já como bispo auxiliar do Rio de Janeiro, D. Leme articula um ambicioso plano pastoral para fomentar a re-cristianização da sociedade brasileira, movendo-se em duas frentes estratégicas principais: a organização de uma "armada" de leigos intelectuais sob direção da Hierarquia, encarregada de promover ampla e continuada intervenção

23. Cf. Salem, Tânia. "Do Centro D. Vital à Universidade Católica". In: Schwartzman, Simon (Org.). Universidades e Instituições Científicas no Rio de Janeiro. Brasília: Cnpq, 1982, pp. 97-134. 
doutrinária junto à sociedade e suas instituições; e o investimento na educação católica, com a campanha a favor do retorno do ensino religioso na escola pública, "direito da maioria católica", e o projeto de criação de uma Universidade Católica, dentre outras iniciativas. Em suma, a pastoral de D. Leme visava substituir o "cristianismo de sentimento" então em voga, frouxo e acomodado, por um "cristianismo mais intelectual", consciente e comprometido. ${ }^{24}$

É nesse contexto que avulta a figura marcante do sergipano Jackson de Figueiredo (1891-1928), braço direito de D. Leme e principal líder leigo da Reação Católica em sua fase inicial. De passado boêmio, anarquista e anti-clerical, converte-se em 1917 ao catolicismo, passando a defendê-lo com a mesma ferócia com que antes o combatia, tornando-se uma espécie de "cangaceiro espiritual" das hostes da Reação Católica. Personalidade carismática, de profunda têmpera existencial, exerceu influência proeminente sobre os intelectuais de sua geração. Escritor de talento, publica, em 1922 - em plena revolução modernista -, Pascal e a Inquietação Moderna, marco do pensamento católico brasileiro. Ardoroso polemista e doutrinador, funda com D. Leme os dois baluartes institucionais da Reação Católica: a Revista A Ordem (1921), emissário oficial do pensamento católico; e o Centro D. Vital (1922), principal núcleo de difusão do pensamento católico, no qual se promoviam cursos, ciclos de estudos, conferências e debates. Jackson dirige o Centro D. Vital desde a fundação até 1928, ano de sua morte precoce, afogado nas águas da Barra da Tijuca durante uma pescaria.

Em termos doutrinários, o pensamento de Jackson de Figueiredo se alinha com o programa da Action Française, movimento católico monarquista fundado por Charles Maurras (1868-1952) na contramão do liberalismo anti-clerical da Revolução Francesa, cujas teses principais podem assim resumir-se: 1) A civilização moderna surge de graves e problemáticas rupturas: filosófica, com Descartes, que põe o eu pen-

24. Cf. Salem, Tânia, op. cit. 
sante como centro da realidade; religiosa, com Lutero, que estabelece relação direta entre o indivíduo e Deus; e política, com a Revolução Francesa, que submete a Igreja ao Estado laico; 2) As posições subjacentes a essas rupturas modernas são: racionalismo, subjetivismo e materialismo, que encerram, respectivamente, razão, sujeito e mundo sobre si mesmos, fechando-os à transcendência divina; 3) A principal conseqüência dessas rupturas é a desordem moral que ameaça toda a sociedade; 4) A salvação da sociedade moderna é sua reunificação espiritual sob o domínio da Igreja Católica; 5) A questão política se reduz à questão moral, e o bom governo é o que garante uma reta ordem moral; 6) A desigualdade social é intrínseca à ordem natural, e não tem como ser superada; 7) A identidade nacional funda-se na identidade religiosa; 8) A cristandade medieval é modelo por excelência de civilização.

Em sintonia com a Action Française, o ideário de Jackson de Figueiredo concentra-se na defesa de Ordem, Autoridade e Hierarquia como princípios espirituais e civilizatórios. Eis a alma de sua obra doutrinária, da pastoral de $\mathrm{D}$. Leme - que encontra nítido eco em algumas das teses acima - e de toda a Reação Católica. Até o surgimento de Gustavo Corção, nos anos 1940, Jackson ficou sendo entre nós o mais extremado e talentoso exemplo de católico anti-moderno, nos planos filosófico (anti-racionalista), estético (anti-modernista), social e político (anti-liberal e anti-comunista).

A obra ensaística de Jackson de Figueiredo presta-se acima de tudo a combater "o bom combate" do apostolado católico em pleno areópago moderno. Contra o romantismo "liberal" e o modernismo "libertário", Jackson qualifica a sua própria literatura de "reacionária", sem dar a este termo o menor acento pejorativo que mais tarde o iria estigmatizar:

Na hora em que o Brasil, se bem que ainda dubitativamente, entra numa fase de reação contra os desmandos de um romantismo político, talvez em parte alguma tão reles e, no entanto, tão poderoso, apraz-me chamar a atenção dos leitores da "Gazeta" para alguns aspectos dessa literatura de reação, anti-revolucionária, 
anti-sentimental, anti-romântica, que vai, ora definidamente católica, ora revestindo-se somente do senso prático social do Catolicismo, não só reduzindo a poeira os abalados créditos das doutrinas individualistas e materialistas, como, de alguns anos para cá, assentando já as bases de uma remodelação social, consciente e positivamente inspirada nos ensinamentos da Igreja. ${ }^{25}$

No entanto, não se faria justiça ao escritor Jackson de Figueiredo reduzindo sua obra a mero instrumento de doutrinação. $O$ ardor apostólico não doma, mas, ao contrário, incita a sua verve literária, fazendo-a atingir alturas expressivas. A esse respeito, é voz corrente que o melhor de Jackson, seja pelas fecundas cintilações intuitivas ou pela força do estilo, encontra-se em sua rica Correspondência, por ele mesmo definida como "Suma Sentimental raciocinada", na qual sua personalidade vibrante e introspectiva se exprime à larga, como se vê nesta carta a Alceu Amoroso Lima, de 24-25 de março de 1928:

Terrível, desequilibrante é, sim, o pecado, o erro moral. Só ele faz medo, só ele pode trazer sob a sensação de pânico o homem cristão, principalmente quando este homem, por temperamento e educação, se sente eternamente atraído pelas maiores alturas e pelos precipícios mais trevosos da vida de tempestade, da vida passional, da vida mesma, que se vai agitando em si própria como se não houvesse Deus e o sangue de Jesus Cristo misturado às suas espumas. ${ }^{26}$

Se Jackson de Figueiredo foi o principal porta-voz da Reação Católica na primeira fase, o padre jesuíta Leonel Franca (1893-1948) foi o seu maior pensador. Teólogo e filósofo de alta envergadura, sobrepõe o debate rigoroso de idéias à doutrinação político-religiosa. Discute as raízes da modernidade em nível teológico, filosófico e histórico, e fundamenta a defesa da Igreja Católica como principal agente civilizador do Ocidente, face à crise de valores da modernidade. Polemiza com o "modernismo teológico" (consubstanciado no Programma dei modernisti,

25. Figueiredo, Jackson de. Literatura Reacionária. Rio de Janeiro: Edição do Centro D. Vital, 1924, p. 17.

26. Idem, Correspondência. Rio de Janeiro: Ed. Agir, 1946, p. 23. 
Roma, 1903), de origem protestante liberal, cujo subjetivismo agnóstico traria, para Franca, sérias implicações panteístas; mas não discute o modernismo artístico. De resto, passa ao largo do debate estético. Sua resoluta crítica da modernidade, sem achaques pessimistas ou nostalgia do passado, é equilibrada por uma robusta confiança na razão haurida na tradição clássica aristotélico-tomista. Sustenta o permanente diálogo entre fé e razão, Igreja e cultura. Na Constituição de 1934, durante o governo Vargas, representa com desenvoltura a posição da Igreja no campo educacional. Católico anti-moderno moderado, diagnostica os limites do racionalismo e subjetivismo de matriz cartesiana, e confronta as correntes críticas do pensamento contemporâneo, tais como o marxismo e a psicanálise, sem derivar disto posições regressivas - à la Action Française - no campo social e político:

Crise de alma e crise de instituições; um abalo profundo que atormenta as consciências e desorganiza a convivência humana, em todos os seus graus, familial, nacional, internacional - eis o espetáculo doloroso que nos oferece a civilização moderna. Só uma ruptura de equilíbrio nas exigências essenciais da nossa natureza pode explicar agitação tão funda. Dir-se-ia que a personalidade e a sociabilidade foram atingidas nas fontes vivas de sua existência e progresso. ${ }^{27}$

Jackson de Figueiredo e Leonel Franca elaboram uma crítica teológico-filosófica da modernidade, indigitando-lhe a racionalidade fechada ao mistério, a subjetividade auto-suficiente, a liberdade arbitrária e desmedida e o cientificismo materialista. Demonstram, porém, pouca ou nenhuma compreensão do modernismo estético, no qual a subjetividade é vivida como autenticidade ou singularidade de estilo; a liberdade afirma-se como pulsão criadora; e a razão se solidariza com os sentidos, numa sábia imersão nos mistérios da terra. No espírito da cruzada antimoderna de Jakcson e Franca - apesar do maior equilíbrio deste -, não parece possível conciliar a aventura da liberdade e a reverência da fé; a

27. Franca, Leonel. A Crise do Mundo Moderno. Rio de Janeiro: Ed. Agir, 1951, p. 238. 
afirmação da singularidade do eu e o respeito à Hierarquia; a explosão criadora da arte e a sujeição à autoridade espiritual; a alegria de criar e a alegria de crer. Difícil, portanto, nesse horizonte espiritual, conceber ou acolher uma "oração modernista", como queria Mário dos padres de seu tempo.

\section{Alceu Amoroso Lima: Ação Católica}

Sucedendo Jackson de Figueiredo na direção da Revista A Ordem e do Centro D. Vital, fulgura o nome solar de Alceu Amoroso Lima (18931983), maior mentor leigo do pensamento católico brasileiro contemporâneo. Crítico literário estabelecido, Alceu converte-se ao catolicismo em 1928, após longa troca de correspondência com Jackson. Entre 192938, à sombra do líder sergipano, finca distância crítica das principais posições fundadoras do pensamento moderno em suas várias versões, assumindo linha anti-liberal, sob o signo da restauração do primado do sobrenatural e da Ordem. Flerta com o integralismo, mas não adere a este em razão de uma irredutível incompatibilidade espiritual que somente mais tarde chega a explicitar-se. De temperamento diametralmente oposto ao de Jackson, é sob o influxo de sua inflamada translucidez, entretanto, que Alceu afinal - e de uma vez por todas - corta amarras com a segurança de uma sensatez bem-pensante para consagrar-se ao Eterno, encontrando no Deus cristão a suprema (des)medida pela qual tudo o mais deve medir-se, assumindo desde então uma atitude de profética relativização de sujeito, razão, mundo e tempo e, em particular, de seu tempo, envolto na vertigem de incessantes rupturas:

As novas gerações adoram o vir-a-ser, quando eu creio que deve existir uma opção necessária pelo ser. Adoram as coisas no tempo, quando sustento o dever de não nos deixarmos vencer pelo tempo. Optam pela subordinação do indivíduo à massa, quando vejo a necessidade de salvar o indivíduo. E, se combatem o aniquilamento do indivíduo, é para libertá-lo incondicionalmente, quando devemos todos livremente restabelecer as fronteiras de nossas próprias indistinções. Amam apenas os esta- 
dos instintivos do espírito, quando a verdade se encontra depois dos estados de intuição intelectual. Cultivam o subconsciente, quando ela está no supraconsciente..$^{28}$

Em fins da década de 1930, sob influência do teólogo Yves Congar e seu artigo seminal "Dieu est-il à droite?"; do escritor Georges Bernanos, militante anti-nazista; do filósofo Jacques Maritain, autor de "Humanismo Integral" (1936) e "Cristianismo e Democracia" (1942); e do Pe Lebret O.P., fundador do centro de pesquisa Economia e Humanismo, de 1942, marco do pensamento social católico, Alceu abandona a herança integrista e abraça a democracia como ideal político-social, encontrandose, afinal, com uma dimensão nuclear de si mesmo, até então oclusa. Devota-se cada vez mais às causas da liberdade e da justiça social, enraizadas em profunda inspiração evangélica. A partir de 1945, deixa de trabalhar como crítico literário especializado para dedicar-se à crítica de idéias, como pensador social. Discute as questões candentes e dialoga com as principais correntes de idéias de seu tempo, dentro e fora do campo eclesial, em fina sintonia com os movimentos de libertação social e política. Dentre outras causas, defende o fim do colonialismo, a ascensão do proletariado, a emancipação feminina e os direitos civis das minorias. Representante brasileiro no Concílio Vaticano II e assessor da OEA, foi um dos maiores adversários públicos do regime militar, como testemunham seus artigos no Jornal do Brasil, a exemplo deste, de 04/02/1975:

Falo por mim. Não pelo povo. Nem por minha geração. Nem por um partido. Não tenho procuração de nenhum deles. Nem falo de mim, do "haissable moi"29 pascaliano. Falo apenas por mim. Por este navegante solitário, sobre os mares e sob os ventos tempestuosos de nossos dias. E do nosso imprevisível e ameaçado aparelho político. Mais ameaçado por seus defensores do que por seus contestantes. Aspiro, como qualquer um, por uma ordem social baseada no respeito efetivo dos direi-

28. Lima, Alceu Amoroso. Adeus à Disponibilidade e Outros Adeuses. Rio de Janeiro: Ed. Agir, 1969, p. 18.

29. "Eu odiável". 
tos humanos e não no terror policial ou conspiratório do terrível ciclo vicioso da subversão clandestina e da repressão implacável. Aspiro por uma liberdade e por uma justiça, não utópicas ou demagógicas, mas realistas, que atendam a todas as camadas sociais. Muito particularmente àquelas que vêm sendo sistematicamente excluídas ou oprimidas. Já verificaram que não há, em nosso Poder Legislativo, representante do povo como se diz, não há um só representante do povo operário? ${ }^{30}$

Como crítico, Alceu demonstra notável compreensão das grandes correntes estéticas contemporâneas. Simpatiza com a insurreição modernista em sua primeira hora, quando muitos a tomavam como surto de "paranóia ou mistificação", criticando, entretanto, os seus excessos mesmo antes de converter-se ao catolicismo. Recebe a estima e pública admiração de alguns dos maiores escritores brasileiros de seu tempo, como Mário de Andrade, Manuel Bandeira, Clarice Lispector e o poeta maior Carlos Drummond de Andrade, o qual the dedica vários poemas, como este, "O escritor", no cinqüentenário de sua atividade literária:

\begin{abstract}
Alceu e Tristão - o nome/ e o pseudônimo ensinam/ uma unidade de alma/ na unidade do amor./ Pois é o amor unidade/multiplicada, e a vida/ quando se recoIhe aos livros/ é para voltar mais vida./ Em cinqüenta anos de letras,/ uma flor desenha as pétalas/ de amoroso convívio:/ o homem livre e ligado./ Livre e ligado a seu próximo/ na larga avenida humana/ em que beleza e justiça/ fazem da espera esperança./ Tristão e Alceu: a mesma/ fiel cristalinidade:/ uma criança sorrindo/ no sábio à sombra de Deus. ${ }^{31}$
\end{abstract}

Alceu escreveu vasta obra, com cerca de 80 volumes, abrangendo as áreas da Literatura, Filosofia, Teologia, Sociologia, Economia, Direito, Jornalismo, Psicologia, formando uma espécie de suma do humanismo cristão brasileiro contemporâneo. Espírito aberto, excepcionalmente equilibrado, universal, liberal. Morre em plena jovialidade de espíri-

30. Apud Carpeaux, Otto Maria. Alceu Amoroso Lima. Rio de Janeiro: Edições Graal Ltda., 1978, p. 114.

31. In Andrade, Carlos Drummond de Andrade. Poesia e Prosa. Rio de Janeiro: Ed. Nova Aguilar, 1988, p. 1071. 
to, recebendo no leito hospitalar livros de Teologia da Libertação, que admira e saúda. Em face deste bosquejo, talvez se possa caracterizar Alceu Amoroso Lima como um católico transmoderno, pois não foge da modernidade, aceita-a, afirma-a, embora com sérias - por vezes severas - reservas. Enraizado na fé cristã, guarda firme distância do perigo entranhado no racionalismo e no subjetivismo modernos e, ao mesmo tempo, adere com ardor aos movimentos de libertação estética, social e política em curso na modernidade, não obstante aquele perigo. Católico transmoderno, pois se situa, como cristão, diante da ambigüidade da modernidade, operando firme e fino discernimento profético entre o "humanismo" - lúcida emancipação - e o antropocentrismo - delírio de onipotência - intrínsecos à civilização moderna:

\begin{abstract}
Vejo no alto da montanha ao longo do caminho percorrido e ao mesmo tempo um pouco por toda parte, marcando a trajetória de inúmeras peregrinações semelhantes a esta, vejo três concepções da vida, três formas de compreensão do mundo, que podemos denominar - o espírito libertário, o espírito totalitário e o espírito trinitário. O primeiro é a caricatura da liberdade humana. O segundo, o decalque monstruoso da totalidade divina. O terceiro é o próprio arcano do universo, o Pai, o Filho e o Espírito Santo, ou, em linguagem menos enigmática, Deus, Cristo e Igreja. Abandonei-me longamente ao primeiro, como posso ver tão claro lá no fundo do vale e até quase no meio da encosta. Namorei de longe o segundo, como entrevejo vagamente lá por meados da ascensão. Entreguei-me definitivamente ao terceiro, quando nele reconheci o Caminho, a Verdade e a Vida. ${ }^{32}$
\end{abstract}

Alceu Amoroso Lima jogou papel decisivo na consolidação da Reação Católica, que, a partir de 1935, sob o comando do já então Cardeal Sebastião Leme, passa a chamar-se Ação Católica. Entre as décadas de 1920 e 1930, Alceu está à frente, com o Cardeal Leme, da formação de uma rede de instituições que contribuem para assegurar a intervenção da Igreja na sociedade: Ação Universitária Católica;

32. Lima, Alceu Amoroso. Adeus à Disponibilidade e Outros Adeuses, op. cit., p. 35. 
Confederação dos Operários Católicos; Instituto Católico de Estudos Superiores, embrião da futura Universidade Católica, fundada no Rio de Janeiro em 1942; Associação de Bibliotecas Católicas; Congregação da Imprensa Católica; Liga Eleitoral Católica etc. Sob a direção de Alceu, o Centro D. Vital amplia o número de sócios e se expande para outros estados brasileiros. ${ }^{33}$ Com forte presença social, a Igreja consegue marcar posição na Constituição de 1934, especialmente no campo educacional, estabelecendo um regime de colaboração com o governo de Getúlio Vargas - nem subserviência ao Estado, como em 1824; nem independência, como em 1891 -, o qual dela se serve como importante aliado na manutenção da ordem social e política, ajudando a conter a ameaça comunista.

\section{O "romance católico"}

Ao lado do Centro D. Vital dirigido por Alceu, destaca-se também o papel cultural jogado pelo Mosteiro de São Bento do Rio de Janeiro, sob as lideranças do jovem abade D. Thomas Keller, destacado teólogo, pregador e conferencista, que funda, no Centro D. Vital, o primeiro curso de Teologia para leigos; e de D. Martinho Michler, diretor do Centro de Liturgia da Ação Universitária Católica, responsável pela renovação litúrgica que atrai maior participação dos leigos na missa. Nessa época, um expressivo número de jovens profissionais liberais resolve consagrar-se à vida monástica no Mosteiro de São Bento, fato registrado por Alceu no artigo "De doutores a monges". ${ }^{34}$

Nesse contexto de revivescência espiritual, a década de 1930 assiste ao florescimento do "romance católico" no Brasil, sob direta influência de escritores ingleses e franceses de inspiração católica, como Julien Green, Graham Greene, François Mauriac, Leon Bloy e Georges Bernanos, o qual viveu foragido no Brasil durante os anos da Segunda

33. Cf. Schincariol, Marcelo Tadeu. "Catolicismo, romance católico e crítica literária no contexto da Revista A Ordem". Revista de Estudos da Religião, no. 4, 2006, pp. 97 e ss. 34. Lima, Alceu Amoroso. In: Revista A Ordem. Rio de Janeiro, abr. 1941, p. 89-95. 
Guerra Mundial. Principais representantes do "romance católico", ente nós, foram Cornélio Pena (1856-1958), fundador do romance de "realismo psicológico" na segunda fase do modernismo brasileiro; Lúcio Cardoso (1912-1968), romancista, poeta e dramaturgo, um dos expoentes da literatura brasileira dos anos 1930; e Otávio de Faria (1908-1980), cunhado de Alceu, escritor denso, com forte carga reflexiva e existencial. Espírito angustiado, francamente anti-moderno e, em política, anti-liberal e anti-comunista, tendo aderido ao integralismo, Otávio de Faria é autor de 13 romances, a que deu o título geral de "Tragédia Burguesa".

Entre as principais características do "romance católico", registramse a primazia da introspecção psicológica e da meditação existencial sobre a descrição da paisagem e do pitoresco; o foco na personalidade do personagem, cuja complexidade e dramas prevalecem sobre a tipificação social; e a predominância da vida urbana cosmopolita e das camadas médias, instruídas, da sociedade, sobre o ambiente regional e popular. O "romance católico" concentra-se na prospecção da alma exilada do homem urbano mediano, sem crenças e ideais, moralmente débil, levado pelos ventos dos novos tempos nos desertos da grande cidade. O preço desse viés é a perda do sentido de povo como sujeito histórico e da terra como lugar de pertença simbólica, como se não fosse próprio ao espírito católico - em sentido literal - a imersão em uma cultura local, com o mistério singular de seus jeitos e temperos. Por outro lado, a distância do regionalismo pitoresco deu ao artista uma inusitada liberdade para expandir-se por obscuras zonas da alma, e aprofundar-se em questões existenciais que dificilmente encontrariam abrigo no calor colorido da paisagem nativa. Como sublinha o escritor católico Barreto Filho em seu artigo "Romance", publicado na Revista A Ordem:

O moderno romance brasileiro é alguma coisa de falso, porque se nega a reconhecer a existência de um drama individual, complexo e interior do homem culto e europeizado, e entretanto preso pelas raízes mais íntimas à sua terra. É um romance que violenta a nossa complexidade psicológica, desconhecendo-a, na atividade objeti- 
va de plasmar o universo visível. É um romance de pura paisagem, e por isso não satisfaz como obra humana, viva. $\dot{E}$ alguma coisa de arquitetônico, de pictural; parece que as mãos é que modelam uma argila exterior a nós mesmos, e que não explica, não abrange por si só toda a significação do homem brasileiro. É por isso que nós nos sentimos muito mais próximos dos livros de Mauriac ou de Julien Green, é porque os dramas que eles desenvolvem nos representam muito mais do que a exaltação de nossa natureza, que encontramos nos nossos romances, e que nos obrigam a estar exteriores a nós mesmos, longe do nosso próprio contato, em face de almas simples, que trabalham a terra e amainam a vida, e que em vão procuramos aproximar como consangüíneos do drama espiritual que suportamos. ${ }^{35}$

\section{Ismael Nery: "um teólogo que dança!"}

Nas décadas de 1920 e 1930, desponta na cena cultural do Rio de Janeiro a figura sui generis de Ismael Nery (1900-1934): funcionário público, pintor precoce e virtuose, de estilo surrealista, com passagem de estudos por Paris, onde frequenta o círculo dos pintores de vanguarda, estreitando laços com Marc Chagall. Imbuído de ardente e esclarecida fé católica, místico e até mistagogo, Ismael Nery exerce ascendência espiritual sobre um grupo reservado de artistas e intelectuais, aos quais não mede esforços para comunicar a força e beleza dos mistérios cristãos, conforme depõe o poeta Murilo Mendes, mais destacado de seus discípulos:

Foi-me dado realizar uma experiência notável: assistir de perto à vida de um místico moderno, circulando nas ruas, nos cafés, nos teatros, nas repartições, procurando extrair de tudo o interesse da verdade religiosa, técnico em adaptação de teorias atuais aos postulados católicos, lutando com um temperamento de fogo, renunciando ao sucesso e às conquistas temporais, fazendo um apostolado inteligente no meio de escritores, poetas e artistas. ${ }^{36}$ 
A simples presença de Ismael raiou no ambiente cultural de seu tempo com a força de uma epifania, como se nela tomasse carne a eterna novidade do Verbo cristão, encoberta pela couraça secular de uma religiosidade moralista e de fachada. Mais que isso, a presença de Ismael revelava o próprio Deus cristão como Presença oferecida ao encontro:

Na verdade, ouvíramos falar de Deus durante toda a nossa infância e adolescência. Mas, por mais virtuosas e respeitáveis que fossem - e o eram - as pessoas que nos inculcaram este princípio supremo, a idéia de Deus se nos apresentava, em geral, desagradável. Deus não passava de um julgador, um espião de nossos atos, um bedel segurando a palmatória. A moral do Antigo Testamento prevalecia sobre a do Novo, uma moral apoiada quase sempre em base negativa, em restrições autoritárias: não faça isso, não faça aquilo, não faça aquiloutro... Chegados à maioridade, nós queríamos logo nos descartar, o mais breve possível, desse incômodo personagem: esse Deus positivamente não tinha parte conosco, sendo alheio aos nossos projetos e ao nosso desejo de libertação. Ismael recolocou em nosso espírito a idéia de Deus, ou melhor, instauroua em bases artísticas, afetivas ou filosóficas, principalmente através da Encarnação do Cristo prolongada na Igreja e nos homens, na vida de cada dia. (...) De fato, a Encarnação do Cristo é a irrupção da eternidade no tempo. (...) Surgia-nos o Cristo como companheiro cotidiano do homem, seu guia no tempo e na eternidade. (...) Surgia-nos o Cristo como o artista máximo, o criador de um grande estilo de vida. ${ }^{37}$

Essa passagem é emblemática. Nela se joga toda uma mudança paradigmática, de alcance dificilmente estimável: aqui, Cristo já não aparece como o soberano monarca à testa de um exército de salvação, mas é o "artista máximo", criador de um "grande estilo de vida" e "companheiro cotidiano do homem". Fica assim esclarecido o título "O Discípulo de Emaús", escolhido por Murilo Mendes para batizar o conjunto de 754 aforismos de nítido espírito ismaeliano, espécie de suma poético-filosó-

37. Idem, ibidem, pp. 42-43. 
fica em homenagem ao mestre, publicada em $1943 .{ }^{38} \mathrm{O}$ título refere-se à passagem narrada no Evangelho de Lucas na qual dois discípulos de Jesus, três dias após a Sua crucificação, caminham taciturnos rumo à aldeia de Emaús, quando deles se aproxima o Ressuscitado, sem que O reconheçam. Diante de seu desânimo, o Visitante explica-Ihes as passagens das Escrituras que prevêem Sua morte e ressurreição, mas nem assim seus olhos se abrem. Chegando a Emaús, os discípulos convidam-nO a passar a noite com eles e, na ceia, quando o Visitante parteIhes o pão, afinal O reconhecem, mas justo então Ele desaparece. É, pois, para este Deus-companheiro, que dialoga, caminha e come junto, e que de tal modo quer estar junto que se faz, Ele próprio, Pão - é para este Deus vivo e invisível que o hermeneuta Ismael Nery abre os olhos dos jovens intelectuais de seu tempo, vedados pela fachada de catolicismo que os impedia divisar a estrada de Emaús.

Com o testemunho de Ismael, no entanto, não é somente o Deus cristão que ganha rosto: mesmo os dogmas e ritos católicos perdem o aspecto de fórmulas embalsamadas e procedimentos automatizados a serviço do poder de hierarcas, para destilarem a imprevista "vibração humana" neles contida: "Ele mostrou a plasticidade e vibração humana do dogma, que infelizmente a maior parte dos interessados transforma em coisa estática e anti-humana." ${ }^{39}$ À presença desse místico artista, que vivia o ritual litúrgico com fervor análogo ao que aplicava na criação de suas obras, a Igreja já não parecia reduzir-se a gigantesco mecanismo institucional encarregado de administrar o sagrado, mas se deixava ver e viver como Corpo Místico, comunidade orante universal em processo de realização aqui e agora, aberta a toda a humanidade e à humanidade toda de cada homem, em todos os tempos e lugares:

Ismael mostrou-nos a fecundidade da tradição católica e sua plasticidade dentro da rigidez de certos princípios

38. Cf. Mendes, Murilo. "O Discípulo de Emaús". In: Poesia Completa e Prosa. Rio de Janeiro: Ed. Nova Aguilar, 1994.

39. Mendes, Murilo. Recordações de Ismael Nery, op. cit., p. 85. 
imutáveis. Mostrou-nos que a própria experiência histórica revela a riqueza e mobilidade da doutrina católica, adaptável a todos os tempos, civilizações e regimes políticos. Dizia-nos sempre que a catolicidade estava começando, pois só agora a humanidade chegara a um estado de madureza necessário à sua própria tomada de consciência. ${ }^{40}$

Ismael era apaixonado pela pessoa de Jesus Cristo, em Quem buscava inspirar-se nos atos mais prosaicos da vida cotidiana e nas mais elevadas criações da arte e do pensamento. Filósofo outsider, dotado de intuição clarividente, não obstante a falta de cultura livresca organizada, esboça um sistema de ideias chamado "essencialismo", cuja base é a intuição de um princípio vital unificador transcendente ao tempo e ao espaço. Embora professasse o seu personalíssimo essencialismo com convicção profética, fazia pouco caso dele, considerando-o mero propedêutico à fé católica, cuja doutrina, se bem compreendida, o tornaria dispensável. Frequentador assíduo do Centro D. Vital e do Mosteiro de S. Bento; devoto de S. Francisco de Assis, foi enterrado com o hábito da Ordem Terceira de São Francisco, à qual pertencia.

Com Ismael Nery, estamos diante de um místico católico (não um católico sem mais), também ele, transmoderno, que compõe tradição espiritual e vanguarda artística, dogma e espírito criador, fidelidade e invenção, reverência e ousadia, Charitas e Eros. Como em nenhum outro, nele a mística e a criação artística se transfundem numa só substância espiritual: "Para ele a vida estética não se opunha à vida filosófica ou religiosa. Vimos diante de nós, realizado, o ideal grego, desenvolvido e completado pela filosofia cristã. Vimos este milagre: um teólogo que dança!"41 Transmoderno porque, como Alceu, deixa-se estar na modernidade, acolhe-a, imerge nela, mas não lhe pertence: “(...) apesar de mergulhado no espírito de seu tempo, não se deixou absorver por ele, mas procurou sempre extrair o eterno do transitório." ${ }^{42}$ Não toma como

\footnotetext{
40. Idem, ibidem, p. 83.

41. Idem, ibidem, p. 93. Grifo nosso.

42. Idem, ibidem, p. 110.
} 
base os pressupostos filosóficos da modernidade - racionalismo, subjetivismo e materialismo -, mas, ao mesmo tempo, abraça os movimentos de libertação estética que permitem expressão mais autêntica do eu artístico. Celebra a força criadora que habita o eu, mas não o diviniza; frui a liberdade, aventura-se nela, mas reconhece-lhe limites e medidas. No plano político, passou ao largo da constringente dicotomia entre integralismo e comunismo, embora discernisse elementos evangélicos no socialismo em sentido lato. Em suma, "Era possível ser em 1930 grande artista, homem moderno e católico romano de confissão e comunhão freqüente. Assim foi Ismael Nery." ${ }^{43}$

\section{Murilo Mendes: o Cristo libertário}

O maior discípulo de Ismael Nery foi o poeta Murilo Mendes (19011975), que manteve convivência diária com o mestre por treze anos. Principal intérprete das idéias de Ismael, de cujo essencialismo torna-se porta-voz em campo poético. Em seguida à morte do "Amigo" - como a ele se referia -, em 1934, e após aguda crise interior, Murilo converte-se ao catolicismo, tornando-se, também ele, freqüentador do Centro D. Vital e do Mosteiro de São Bento. Dotado de ingênita força criadora, é considerado por Manuel Bandeira, no início da década de 1930, como um dos "bichos-da-seda" de nossa literatura, isto é, "os que tiram tudo de si mesmos" ${ }^{44}$ Herdeiro da estética modernista, desde o seu livro de estréia escreve em versos livres, fazendo incursão episódica pelo pitoresco e pelo poema-piada em "História do Brasil" (1932). Foi um de nossos mais profundos conhecedores da literatura de vanguarda, cujas várias vertentes - especialmente a surrealista - assimila com maestria, levandoas a uma expressão decantada e madura. Até o fim da vida, será um incansável pesquisador da linguagem artística. Em 1957, Murilo passa a lecionar Literatura Brasileira na Universidade de Roma, onde fixa residência. Casado com a poetisa portuguesa Maria da Saudade Cortesão,

43. Idem, ibidem, p. 28.

44. Apud Mendes, Murilo. Poesia Completa e Prosa, op. cit., p. 35. 
sua casa em Roma é ponto de encontro de escritores, artistas e intelectuais de vanguarda. Em 1973, recebe o Prêmio Internacional de Poesia Etna-Taormina, um dos mais importantes da Europa. Gênio visceralmente inventivo, faz da Arte o seu campo de pesquisa dos enigmas da existência, sua luta contra toda forma de injustiça e tirania, seu sacerdócio e apostolado. Em 1935, publica o livro "Tempo e Eternidade", escrito a quatro mãos com o "companheiro de armas espirituais" Jorge de Lima, com o impactante lema: "Restauremos a Poesia em Cristo". Seguem-se "Poesia em Pânico" (1938), "O Visionário" (1941), "As Metamorfoses" (1944), "Poesia Liberdade" (1947), entre outros. Libertário e anti-totalitário por excelência, dado a rompantes excêntricos, em plena II Guerra Mundial escreve telegrama pessoal ao ditador Adolf Hitler em protesto contra a invasão de Salzburg, terra do compositor Wolfgang Amadeus Mozart, de quem era fã ardoroso.

Em Murilo - no rastro de Ismael -, o ser humano é concebido à medida do Eterno, fonte absoluta de criação e redenção, que o impele a um incessante movimento de transcendência para além de um eu fraturado e encerrado em si mesmo: "Senhor do mundo,/ cada vez que ressuscitas um homem, me destruo a mim mesmo. (...) Senhor do mundo,/ me tira de mim pra que eu possa olhar os outros e eu mesmo." ${ }^{45}$; transcendência, ainda, para além de um mundo dilacerado em fronteiras políticas e ideológicas:

Eu sou da raça do Eterno./ Fui criado no princípio/ E desdobrado em muitas gerações/ Através do espaço e do tempo./ Sinto-me acima das bandeiras,/ Tropeçando em cabeças de chefes./ Caminho no mar, na terra e no ar./ Eu sou da raça do Eterno,/ Do amor que unirá todos os homens:/ Vinde a mim, órfãos da poesia,/ Choremos sobre o mundo mutilado. ${ }^{46}$

Transcendência, enfim, que abre o poeta a uma solidariedade universal:

45. "Vidas opostas de Cristo e de um homem". Idem, ibidem, p. 107.

46. "Filiação". Idem, ibidem, p. 250. 
Sou ligado pela herança do espírito e do sangue/ Ao mártir, ao assassino, ao anarquista, / Sou ligado/ Aos casais na terra e no ar,/ Ao vendeiro da esquina,/ Ao padre, ao mendigo, à mulher da vida,/ Ao mecânico, ao poeta, ao soldado,/ Ao santo e ao demônio,/ Construídos à minha imagem e semelhança. ${ }^{47}$

Por vezes, a voltagem "pânica" da poesia de Murilo - paroxismo da liberdade no afã de sua definitiva libertação - parece repousar na intimidade do Mistério pelo qual anseia, e desse encontro maior nasce o louvor:

Eu te proclamo grande, admirável,/ Não porque fizeste o sol para presidir o dia/ E as estrelas para presidirem a noite;/ Não porque fizeste a terra e tudo que se contém nela,/ Frutos do campo, flores, cinemas e locomotivas;/ Não porque fizeste o mar e tudo que se contém nele,I Seus animais, suas plantas, seus submarinos, suas sereias:/ Eu te proclamo grande e admirável eternamente/ Porque te fazes minúsculo na Eucaristia/ Tanto assim que qualquer um, mesmo frágil, te contém. ${ }^{48}$

No já mencionado "Discípulo de Emaús", tem-se uma amostra condensada do pensamento cristão-essencialista de Murilo, em que se desvelam:

O sprit de finesse do mistério cristão: "A suprema delicadeza de Jesus Cristo consiste em ter ocultado até o último instante a sua Divindade." ${ }^{9}$; "A doutrina católica é supremamente elegante." mais, e Deus de menos." ${ }^{51}$

Os limites da civilização moderna: "O burguês é o homem que não crê na Transubstanciação." "52; "O mundo moderno perdeu a crença no Espírito Santo e no Espírito do Mal. Por isso a ação do primeiro sofre

47. "Solidariedade". Idem, ibidem, p. 205.

48. "Salmo no. 3". Idem, ibidem, p. 251.

49. Idem, ibidem, p. 818.

50. Idem, ibidem, p. 838.

51. Idem, ibidem, p. 821.

52. Idem, ibidem, p. 819. 
constrangimento, enquanto o segundo pode operar à vontade." ${ }^{53}$

A irredutibilidade do Evangelho a ideologias: "O comunismo é revolucionário diante do capitalismo, e conservador diante do cristianismo." ${ }^{54}$

A dimensão cósmica e humana do Cristo: "Jesus Cristo é o grande sacramento do Universo." ${ }^{5}$; "Cristo decifra o homem."

Murilo Mendes foi, como Alceu e Ismael, um católico transmoderno - com gradual radicalização modernizante no campo estético -, compondo tradição espiritual e vanguarda artística, dogma e espírito criador, fidelidade e invenção, sem ir tão fundo na espiritualidade mística de seu mestre, e indo ainda mais longe na experimentação estética. Posicionase de modo crítico em relação aos desvios filosóficos da modernidade, mas adere aos movimentos de emancipação social e política, inclinandose a um nada enquadrável anarco-socialismo cristão. Em suma, tradicional no plano espiritual-filosófico; revolucionário no plano político-social; e libertário em estética. Para Murilo e Ismael, compor uma "oração modernista" é não somente uma possibilidade estética legítima, mas uma injunção histórica inevitável. Trata-se, apenas, de expressar a sensibilidade de seu tempo - não apenas a forma - e dialogar com Deus a partir dela.

\section{Jorge de Lima: o Cristo telúrico}

Irmão de fé e parceiro de poesia de Murilo Mendes, Jorge de Lima (1893-1953) foi criado no interior de Alagoas. Profundamente marcado pela infância despojada e solta às margens do rio Mundaú, teve a primeira grande experiência poética aos oito anos, do alto da Serra da Barriga, diante de sua paisagem natal. Jorge formou-se numa religiosidade católica provinciana, fortemente ritualística e simbólica, terna e telúrica, que o

53. Idem, ibidem, p. 835.

54. Idem, ibidem, p. 829.

55. Idem, ibidem, p. 841.

56. Idem, ibidem, p. 855. 
marca para o resto da vida, junto às reminiscências da infância. Formado em Medicina, na década de 1930 muda-se com a família para o Rio de Janeiro, onde estabelece consultório médico. A distância da terra natal e as intensas transformações urbanas e sociais o levam a uma experiência aguda de exílio interior. Em 1935, após período de crise existencial, reencontra a fé católica, agora assumida em toda sua exigência espiritual e teológica. Foi frequentador regular dos cursos e conferências no Centro D. Vital, e das missas e retiros no Mosteiro de São Bento. Além de Murilo, foi também amigo de Alceu e Bernanos. Jorge inicia-se na poesia com versos parnasianos de fina lavra, que lhe rendem o título de "Príncipe dos Poetas Alagoanos" (1914). Converte-se à estética modernista por necessidade de libertação expressiva, advindo daí os poemas da fase "regional", de alma telúrica e popular, com cheiro, cor e sabor de infância nordestina, dos quais "Essa Nega Fulô" é o mais famoso. Mesmo sem a exuberância vanguardista do parceiro Murilo Mendes, sua poesia atravessa sucessivos ciclos de experimentação formal. Depois de "Tempo e Eternidade", os versos se tornam mais longos, ganhando ritmos semelhantes aos dos versículos bíblicos, como em "A Túnica Inconsútil" (1938). A força imaginativa de sua poesia intensifica-se cada vez mais até atingir vertigens oníricas de marcante tendência surrealista, cujo ponto mais alto é Invenção de Orfeu, obra prima de Jorge de Lima, portento poético em dez cantos e milhares de versos, espécie de oceano poético em que deságua toda a criação literária, de inspiração brasileira e cristã, do poeta alagoano. Infância, terra, povo e fé constituem, de fato, o núcleo de sua inspiração. Após prolongada enfermidade, que suporta com tocante contrição espiritual, morre em "olor de santidade", como testemunha a oração registrada no diário do poeta poucos dias antes de sua morte:

Eu, o pobre de espírito, abro a minha alma ao Vento Violento que abalou o Cenáculo; e à maturidade da Graça a ofereço, pois ao Espírito Santo, que é o amor do Pai e do Filho, alegria do Pai e do Filho e a Paz que os une; a Ele peço que seus dons me penetrem, infu- 
sos me libertem e me façam misericordioso para que eu alcance misericórdia e iluminem a mim, pobre de espírito, com a presença de Deus e sua paciência, e sua doçura, e sua bondade, e sua benignidade, e sua longanimidade para que eu me pertença à fé, à modéstia, à temperança e à castidade; e que eu, pobre de espírito, me revista de seus poderes e ganhe resistência sobrenatural para merecê-los no exílio de minha vida mortal e na adoração eterna da Santa Face de Deus, amém. ${ }^{57}$

Na singela "Oração", de 1927, exprime-se a terna piedade provinciana da fase regional do poeta:

\begin{abstract}
"Ave Maria cheia de graça..."' A tarde era tão bela, a vida era tão pura,/ as mãos de minha mãe eram tão doces,/ havia, lá no azul, um crepúsculo de ouro... lá longe.../ - "Cheia de graça, o Senhor é convosco, bendita!/ Bendita!"/ Os outros meninos, minha irmã, meus irmãos menores, meus/ brinquedos, a casaria branca de minha terra, a bur-/ rinha do vigário pastando junto à capela... lá longe/ Ave cheia de graçal - "bendita sois entre as mulheres, bendito é o fruto do vosso/ ventre..."/ E as mãos do sono sobre os meus olhos,/ e as mãos de minha mãe sobre o meu sonho,/ e as estampas de meu catecismo/ para o meu sonho de ave! $!^{58}$
\end{abstract}

Após o reencontro do poeta com a fé católica, na década de 1930, sua religiosidade provinciana transmuda-se em espiritualidade teológica, de funda raiz evangélica e amplitude universal, aberta às mais diversas e adversas dimensões do humano, católica no mais estrito sentido, da qual é testemunha o monumental "Poema do Cristão", de 1938, vertido para o francês, publicado em revistas e meditado em mosteiros da Europa:

Porque o sangue de Cristo/ jorrou sobre os meus olhos,/ a minha visão é universal/ e tem dimensões que ninguém sabe./ Os milênios passados e os futuros/ não me aturdem, porque nasço e nascerei,/ porque sou uno com todas as criaturas, / com todos os seres, com todas as coisas/ que eu decomponho e absorvo com os sentidos/ e compreendo com a inteligência/ transfigurada em

57. Lima, Jorge de. "Diário". In: Obra Completa. Rio de Janeiro: Ed. José Aguilar Ltda., 1958, p. 159.

58. Idem, ibidem, p. 237. 
Cristo./ Tenho os movimentos alargados./ Sou ubíquo: estou em Deus e na matéria;/ sou velhíssimo e apenas nasci ontem,/ estou molhado dos limos primitivos,/ e ao mesmo tempo ressôo as trombetas finais,/ compreendo todas as línguas, todos os gestos, todos os signos,/ tenho glóbulos de sangue das raças mais opostas./ Posso enxugar com um simples aceno/ o choro de todos os irmãos distantes./ Posso estender sobre todas as cabeças um céu unânime e es-/ trelado./ Chamo todos os mendigos para comer comigo,/ e ando sobre as águas como os profetas bíblicos./ Não há escuridão mais para mim./ Opero transfusões de luz nos seres opacos,/ posso mutilar-me e reproduzir meus membros, como as estrelas/ do mar,/ porque creio na ressurreição da carne e creio em Cristo/, e creio na vida eterna, amém! ${ }^{59}$

Jorge de Lima foi, como Alceu, Ismael e Murilo, um católico transmoderno. Tradicional, piedoso, beatífico, e mesmo místico, no plano espiritual; crítico da subjetividade auto-suficiente e do racionalismo da modernidade, no plano filosófico; conservador, quase retrógrado, no plano político, de tendência anti-comunista, não obstante o entranhado senso de solidariedade social haurido na própria fé cristã; experimental, insubmisso, em estética, pela necessidade de dar vazão à pujante força criadora de que é dotado. Inaugura, no campo cultural católico, uma vertente estética telúrica e popular. Em sua poesia, o Cristo abraça o barro brasileiro.

\section{Hélio Pellegrino: "Transformação” católica?}

Chegamos, enfim, a Hélio Pellegrino (1924-1988), errática voz católica - ou "paracatólica" - em meio à convulsão social, política, cultural e comportamental da segunda metade do século XX. Intempestivo, misto de perscrutador de almas, filósofo (também ele) outsider, poeta e revolucionário, saído do ventre das Minas para o sol da Guanabara, espécie de elo de ligação entre os mistérios da fé católica e a explosão libertária da contracultura. Com os amigos Fernando Sabino, Otto Lara Resende

59. Idem, ibidem, p. 425. 
e Paulo Mendes Campos, forma o grupo dos "quatro mineiros". Médico psiquiatra com formação em psicanálise, estabelece concorrido consultório psicanalítico no Rio de Janeiro, onde residiu. Colabora em vários jornais, intervindo nas questões de seu tempo com estilo vibrante e combativo. Ferrenho adversário do regime militar, é preso por dois meses sob acusação de militância comunista. Funda, com outros colegas, a Clínica de Psicanálise Social, com objetivo de facultar acesso gratuito da população de baixa renda à clínica psicanalítica. É desligado da Sociedade Brasileira de Psicanálise por haver acusado a instituição de conivência com o regime militar. Foi um dos membros fundadores do Partido dos Trabalhadores, no qual veio a formar um núcleo anti-burocrático no ano seguinte ao de sua fundação.

De profunda fé católica, Hélio mantém vivo o testemunho cristão em meio à ebulição dos anos 1960, promovendo rico diálogo entre o cristianismo e algumas das mais importantes correntes críticas do pensamento contemporâneo, a exemplo da psicanálise e do marxismo, que já fazem uma revisão dos fundamentos da própria modernidade. Identifica-se com o aggiornamento eclesial do Concílio Vaticano II e adere à Teologia da Libertação, criando com Frei Betto o grupo de estudos e oração Mística e Revolução (MIRE). É praticamente a única voz de leigo católico - ou paracatólico - que se faz ouvir, com respeito e admiração, pelos jovens intelectuais da esquerda e da contracultura, pois, a essa altura, a voz humanista do decano Alceu só alcança as gerações mais antigas. Foi amigo de Mário de Andrade, com quem se correspondeu até à morte deste. Escritor bissexto de grande talento, deixou volumes de crônicas e poesias. Em Hélio convivem, em alto grau, uma intransigente exigência de justiça social, indomável rebeldia política, vigorosa inspiração poética e, perpassando e unificando tudo, entranhado senso do Mistério e da Transcendência. Nele a fome de justiça, liberdade e beleza se transfundem em fome de Infinito, pelo qual suspirou apaixonadamente até o fim de sua vida. É um místico cristão em tempos de contracultura, inculturado nos trópicos mestiços afro-ameríndio-latinoamericanos: 
[Nós, latinoamericanos,] Somos, no mundo, o território da dança e do sagrado, onde a negritude é o santo óleo de Eros, capaz de vencer a morte e defender a primavera. Nosso patrimônio fundamental não é tecnológico - mas poético e mágico. Levantamos até o céu o rumor de tambores e batucadas, para que as constelações se rejubilem pelo conhecimento que temos da cadência do Cosmo. Somos libertários e desregrados, portadores de uma alegria que já é o sal da terra, apesar da fome, da miséria, e das chagas que nos vulneram. Por isso, nossos poetas voam tão alto. ${ }^{60}$

A espiritualidade crístico-cósmica de Hélio, maturada em venerável tradição cristã católica de nítido acento chardaniano ${ }^{61}$, é um terno aceno dirigido à juventude transviada em rotas lisérgico-esotéricas:

Vivemos e pisamos o mistério, a carne do mundo, suas cores, asperezas e doçuras. Temos, com relação ao mundo material, uma cumplicidade impensável, silenciosa, profunda, feita de linfas, de humores, de vilosidade, de reentrâncias e saliências, de tripa, nervo - e sangue. O místico, tanto quanto o materialista honrado, aspira a uma absoluta intimidade com a matéria. Ele consegue escapar à mistificação de uma racionalidade presunçosa, que pretenda substituir o Universo concreto por um diamante matemático, que seria a sua essência - ou o seu espírito. O místico, ao religar-se ao Cosmo, ao pôrse de acordo com a respiração - com o ritmo - de Deus, fica em silêncio, num barato indizível. ${ }^{62}$

Lançada ao olho do furacão dos tempos modernos, a alma contemplativa de Hélio permanece recolhida à raiz do mistério cristão, como se vê no ouro de mina desta prosa poética, grave de silêncio e intimidade espiritual, que desvela com delicadeza a jovialidade do Verbo encarnado:

Deus é paciente, o tempo de Deus é todo o tempo. Deus não tem pressa. Ele se mistura ao nosso barro, nasce, vive, morre e ressuscita conosco. O companhei-

60. Pellegrino, Hélio. "Os santos óleos de Eros". In: A Burrice do Demônio. Rio de Janeiro: Ed. Rocco, 1988, p. 152.

61. Alusão ao "Cristo Cósmico" do pensador jesuíta Teilhard de Chardin (1881-1955).

62. Pellegrino, Hélio. "A véspera de Deus”. In: A Burrice do Demônio, op. cit., p. 107. 
ro. Cristo, companheiro, acompanhante, acompanhado. $\mathrm{O}$ amigo, o viandante, o peregrino, senhor do Verbo, o próprio Verbo. Cristo é a juventude do mundo. Sua esperança. Sua tenaz - terna, eterna - esperança. Lâmina afiada, espada vulnerante, irresistível. ${ }^{63}$

A manter-se a nomenclatura até aqui adotada, diríamos que Hélio Pellegrino foi um paracatólico ultra-moderno. Recusa a hipertrofia do sujeito e da razão intrínseca à modernidade, mas aceita a lucidez crítica de "mestres da suspeita" "pós" (ou "hiper") modernos - como Nietzsche, Marx, Freud -, que acusam a cumplicidade do cristianismo histórico com aspectos problemáticos do establishment, no âmbito de uma revisão crítica da civilização ocidental. É libertário - quiçá incendiário - em política; revolucionário no plano social; herdeiro da liberação estética modernista; reformador no plano eclesial; e, no entanto, permanece fielmente filiado à revelação cristã. Desconfia que a sacralização da "Ordem" possa legitimar linguagens caducas, regimes opressivos e sistemas injustos. Aspira mais à construção u-tópica do Futuro do que à restauração nostálgica do Passado. Não acredita que nenhuma época passada estivesse à altura das mais profundas aspirações humanas. Vive a Boa Nova menos como Reação, ou mera Ação, do que como permanente Transformação profética do presente rumo ao Reino sempre além.

A questão, que ora se impõe, é: em que medida o "paracatolicismo" de Hélio Pellegrino, que o tangeu para a margem do catolicismo vigente devido a suas ousadias político-sociais, não se assemelha ao "paracatolicismo" de Mário de Andrade - mestre de Hélio -, igualmente marginalizado devido a suas ousadias estéticas? Em que medida a cultura católica hegemônica, tão ciosa em conservar a Ordem, não perdeu de vista o fermento profético desses escritores contra-culturais de tão visceral inspiração cristã?

A questão, portanto, hoje, e quiçá mais ainda hoje, é: ainda é "pecado" ousar uma "oração modernista"? É legítimo conciliar a reverência da

63. Idem, Meditação de Natal. São Paulo: Ed. Planeta, 2003, fragmento VII. 
fé e a aventura da liberdade? Guardar a alma da Tradição e aceitar as imprevistas reviravoltas históricas? Conciliar obediência espiritual e ousadia cultural? Integrar Charitas e Eros? Em suma, é legítimo ousar crer e ousar criar? E o inverso: acaso é possível, em sociedade francamente secularizada, assumir a aventura humana sem fechar-se à sabedoria da fé? Ousar criar sem desprezar a ousadia de crer?

Nesse sentido, como diria o poeta Ferreira Gullar, "traduzir uma parte na outra parte, que é uma questão de vida e morte - será arte?”.

\section{Referências bibliográficas:}

ANDRADE, Carlos Drummond de Andrade. Poesia e Prosa. Rio de Janeiro: Ed. Nova Aguilar, 1988.

ANDRADE, Mário de. O Empalhador de Passarinho. São Paulo: Livraria Martins Editora, 1972.

- Cartas de Mário de Andrade a Murilo Miranda. Rio de Janeiro: Ed. Nova Fronteira, 1981.

. Poesias Completas. São Paulo/Belo Horizonte: EDUSP/ Editora Itatiaia, 1987.

. Cartas a Anita Malfatti. Rio de Janeiro: Forense Universitária, 1989.

CARPEAUX, Otto Maria. Alceu Amoroso Lima. Rio de Janeiro: Edições Graal Ltda., 1978.

FERNANDES, Lygia (Org.) 71 Cartas de Mário de Andrade. Rio de Janeiro: Livraria São José, s/d.

FIGUEIREDO, Jackson de. Literatura Reacionária. Rio de Janeiro: Edição do Centro D. Vital, 1924. . Correspondência. Rio de Janeiro: Ed. Agir, 1946.

FRANCA, Leonel. A Crise do Mundo Moderno. Rio de Janeiro: Ed. Agir, 1951.

LIMA, Alceu Amoroso. Adeus à Disponibilidade e Outros Adeuses. Rio de Janeiro: Ed. Agir, 1969.

LIMA, Jorge de. Obra Completa. Rio de Janeiro: Ed. José Aguilar Ltda., 1958.

MENDES, Murilo. Poesia Completa e Prosa. Rio de Janeiro: Ed. Nova Aguilar, 
1994.

. Recordações de Ismael Nery. São Paulo: EDUSP, 1996.

MORAES, Marco Antônio de (Org.). Correspondência - Mário de Andrade \& Manuel Bandeira. São Paulo: EDUSP/IEB, 2000.

PELLEGRINO, Hélio. A Burrice do Demônio. Rio de Janeiro: Ed. Rocco, 1988. . Meditação de Natal. São Paulo: Ed. Planeta, 2003.

SANTOS, Luciano Costa. O Passeio da Coruja. Rio de Janeiro: Ed. Leviatã, 1994.

SCHINCARIOL, Marcelo Tadeu. "Catolicismo, romance católico e crítica literária no contexto da Revista A Ordem". Revista de Estudos da Religião, no. 4, 2006.

SCHWARTZMAN, Simon (Org.). Universidades e Instituições Científicas no Rio de Janeiro. Brasília: Cnpq, 1982.

SILVEIRA, Tasso da. Definição do Modernismo Brasileiro. Rio de Janeiro: Edições Forja, 1932.

TELES, Gilberto Mendonça. Vanguarda Européia e Modernismo Brasileiro. Rio de Janeiro: Ed. Record, 1987, 10a ed. 